\title{
Epithelial-myoepithelial carcinoma on lower lip and microinvasive verrucous carcinoma in vocal cord: Case report
}

\author{
(D) Begum Calim Gurbuz, ${ }^{1}$ [D Murat Hakan Karabulut, ${ }^{1}$ (D) Burak Karabulut, ${ }^{2}$ (i) Merve Aydemir, ${ }^{1}$ \\ D Hande Nur Inceman, ${ }^{1}$ (D) Itır Ebru Zemheri ${ }^{1}$ \\ ${ }^{1}$ Department of Pathology, Health Sciences University, Umraniye Training and Research Hospital, Istanbul, Turkey \\ ${ }^{2}$ Department of Otolaryngology, Istanbul Health Sciences University, Umraniye Training and Research Hospital, Istanbul, Turkey
}

\begin{abstract}
Epithelial-myoepithelial carcinoma is a biphasic low-grade malignant tumor, which represents approximately $1 \%$ of all salivary gland tumors. This tumor occurs mostly in the parotid gland, followed by submandibular gland and minor salivary glands. Women, mostly fifth to the eighth decade of life, are commonly affected. Histopathologically, epithelial-myoepithelial carcinoma is composed of an inner single layer of eosinophilic cuboidal ductal cells and outer single or multiple layers of clear myoepithelial cells. We present a case of a 69 years old man who had a scar on lower the lip for 10 years and voice annoyance for three months. The biopsy for lower lip was reported "infiltrative clear cell epithelioid neoplasm" and vocal cord biopsy result was "verrucous carcinoma". After cordectomy and wedge resection of the lower lip, histopathology revealed Epithelial-Myoepithelial Carcinoma for the lower lip and microinvasive verrucous carcinoma for the left vocal cord. Our case has a very uncommon location and presentation for EMC. The tumor location was minor salivary glands of the lower lip and the clinical presentation was quite different. Coexistence with microinvasive verrucous carcinoma of the vocal cord is the other unique part of our case.

Keywords: Epithelial myoepithelial carcinoma; microinvasive; minor salivary glands; verrucous carcinoma.
\end{abstract}

Cite this article as: Calim Gurbuz B, Karabulut MH, Karabulut B, Aydemir M, Inceman HN, Zemheri IE. Epithelial-myoepithelial carcinoma on lower lip and microinvasive verrucous carcinoma in vocal cord: Case report. North Clin Istanb 2020;7(2):187-191.

7 pithelial-myoepithelial carcinoma $(\mathrm{EMC})$ is a rare tumor, which represents approximately $1 \%$ of all salivary gland tumors [1]. EMC was first described in 1972 by Donath et al. [2]. EMCbecame a distinct clinical entity in WHO Classification 1991 [3]. This tumor occurs mostly in major salivary glands, especially in the parotid gland. In addition, cases affecting minor salivary glands, larynx, hypopharynx, maxillary sinus and trachea have also been reported [4]. Its peak occurrence is seventh decades of life and patients are mostly women [5].
Epithelial-myoepithelial carcinoma is usually clinically silent and presents as a slow-growing mass [6] EMC is a biphasic low-grade malignant tumor composed of ductal and myoepithelial structures. Single layer of eosinophilic cuboidal ductal cells are surrounded by a single or multiple layers of clear myoepithelial cells [5].

In this study, we report a case that had very uncommon location and presentation for EMC. It was located in minor salivary glands of the lower lip. The clinical presentation was ulceration on the lip. The patient also had verrucous carcinoma on vocal cords.

Received: December 02, 2017 Accepted: June 25, 2019 Online: July 02, 2019

Correspondence: Dr. Begum CALIM GURBUZ. Saglik Bilimleri Universitesi, Umraniye Egitim ve Arastirma Hastanesi, Patoloji Klinigi, Istanbul, Turkey.

Tel: +90 5433290053 e-mail: begumcalim@hotmail.com

(c) Copyright 2020 by Istanbul Provincial Directorate of Health - Available online at www.northclinist.com 


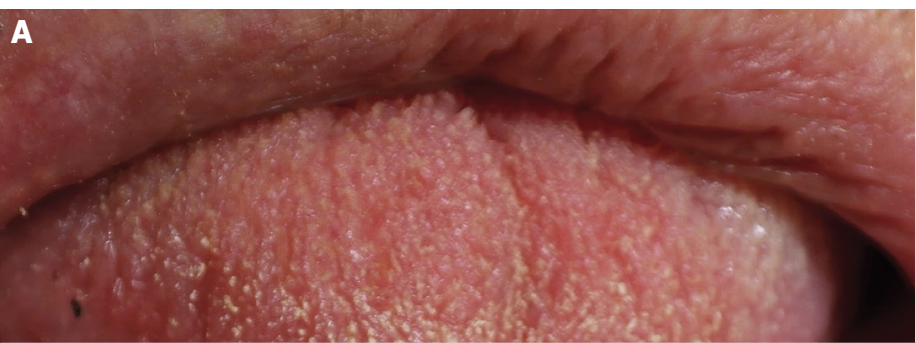

FIGURE 1. (A) Ulcerated lesion on the mucosal side of the lower lip. (B) Nodular lesion on the skin.

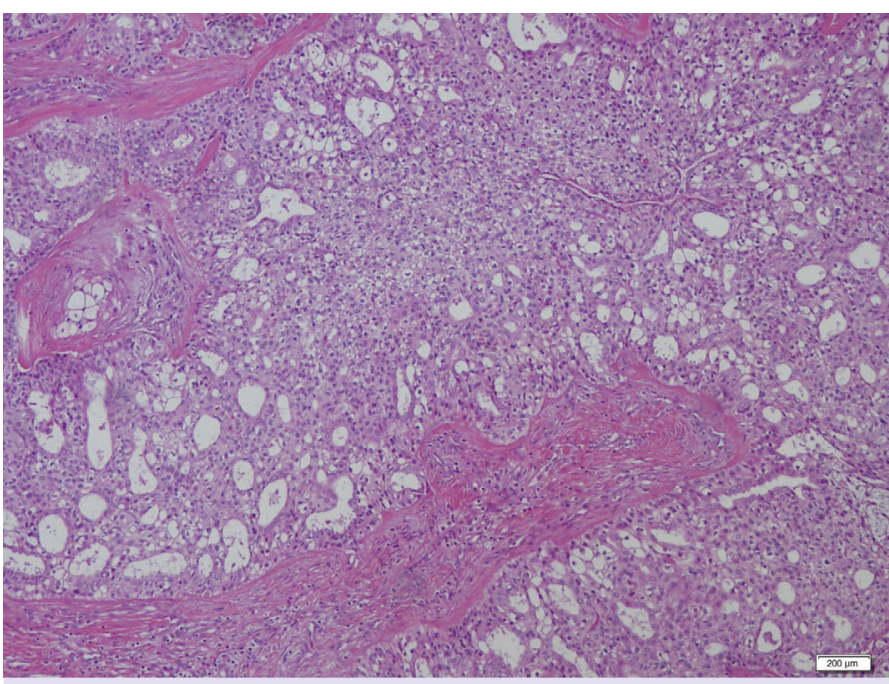

FIGURE 2. Bicellular architecture, outer clear polygonal myoepithelial cells and inner cuboidal duct-like cells.

\section{CASE REPORT}

A 69-year -old male patient, former smoker (40 packageyear), was admitted to our out-patient clinic for a lower lip mass with a one year-duration growth. Mass was located on the skin $0.5 \mathrm{~cm}$ below the lower lip-vermillion border in the median line. The lesion measured approximately $2 \times 1.5 \mathrm{~cm}$. The lesion was continuous through the oral mucosa. It was non-tender, non-compressible nodular mass without any pulsation on the skin side. Howev$\mathrm{er}$, on the oral mucosal side, the lesion was ulcerative centrally (Fig. 1A, B). There was no palpable cervical lymph node. Skin lesion was the reason for the admission and the patient was unaware of oral mucosal involvement. MR showed a lesion with peripheral contrast in the submental area and its size was approximately $27 \times 17 \mathrm{~mm}$. A biopsy was taken from there, and histopathologically, it was an infiltrative clear cell epithelioid neoplasm. The differential diagnosis was including tumors of salivary glands and adnexal tumors. The patient also had voice annoyance for three months. He had a vocal cord biopsy
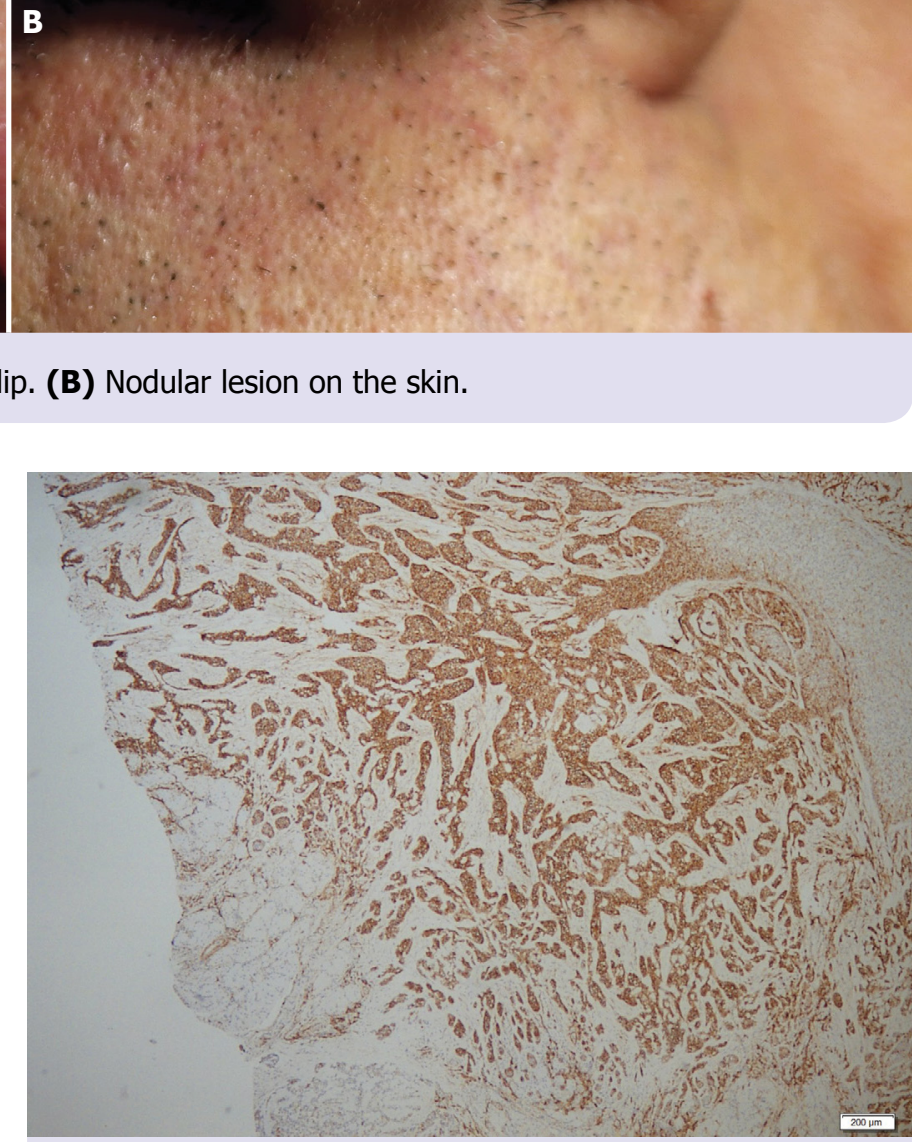

FIGURE 3. EMA staining in ductal cells. On the left side, there is no staining in myoepithelial cells.

from another hospital. The pathology report was compatible with verrucous carcinoma. Upon this, the patient underwent cordectomy for verrucous carcinoma and wedge resection of the lower lip for the ulcerated lesion.

On gross examination of wedge resection of the lower lip, there was an ulsero infiltrative tumoral lesion on the skin. Its size was $2 \times 2 \times 1.5 \mathrm{~cm}$. Histopathologically, the tumor, under the ulcerated epithelium, had an invasive growth pattern to the dermis, resulting in multiple tumor nodules between the sclerotic stroma. The tumor showed bicellular architecture, clear polygonal myoepithelial cells and cells forming duct with round central nuclei (Fig. 2). Mild atypia was seen; there were no atypical mitoses and perineural invasion.

Immunohistochemically, epithelial cells forming duct were positive for EMA (Fig. 3), Pan-CK, CK7, the myoepithelial cells were positive for p63, p40 (Fig. 4), HMWCK (Fig. 5), CK5/6. Ki-67 index was \%5 (Fig. 6) and p53 had wild type expression.

In two vocal cords, there were verrucous carcinoma 


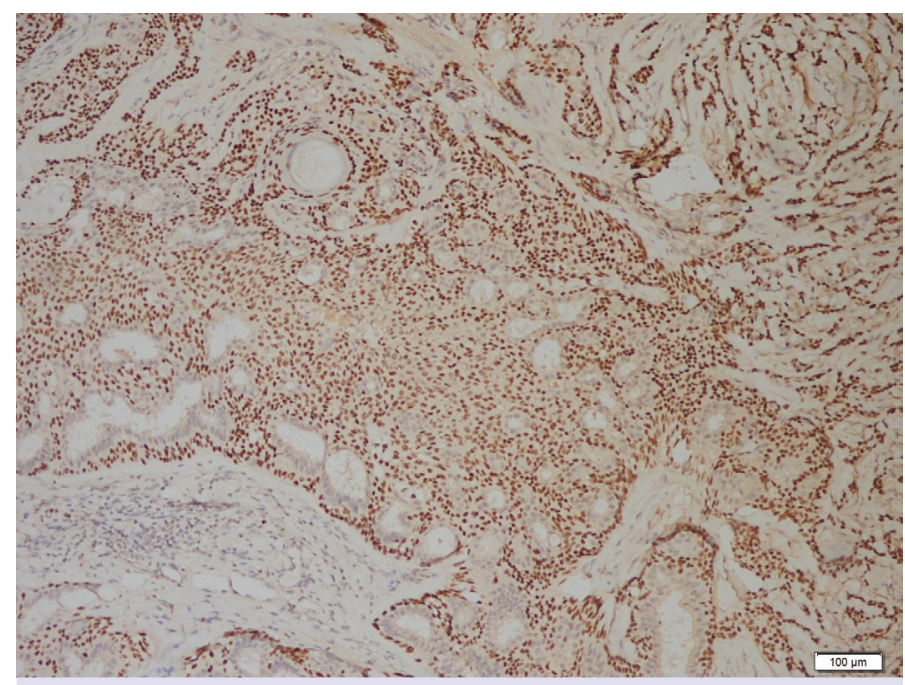

FIGURE 4. p40 staining in myoepithelial cells. The bicellular architecture is seen clearly with this staining. Myoepithelial cells express p40, unlike ductal cells, do not express p40.

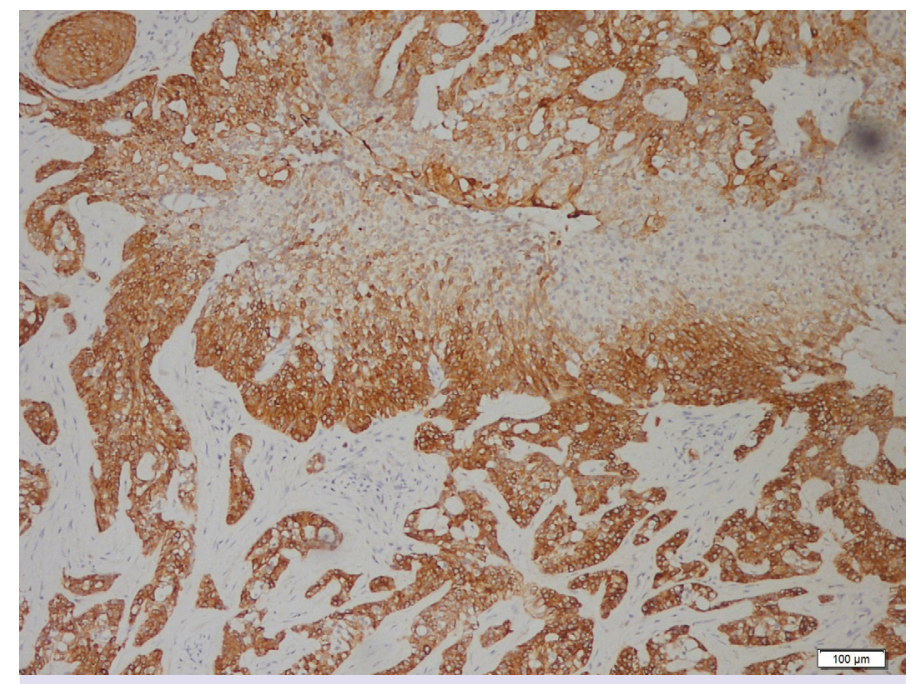

FIGURE 5. Myoepithelial cells stain with HMWCK at the bottom. In the middle of the figure, ductal cells do not express HMWCK.

(Fig. 7). The tumor size was $1.5 \mathrm{~cm}$ in the left vocal cord and $0.9 \mathrm{~cm}$ in the right vocal cord. In the left vocal cord, microinvasion was seen (Fig. 8). There was no lymphovascular invasion or perineural invasion. Patient's consent was obtained for this study.

\section{DISCUSSION}

EMC is a low-grade malignancy, rarely transforms to high-grade or dedifferentiated EMC [4]. It mostly arises in the major salivary glands, the rate of involving minor

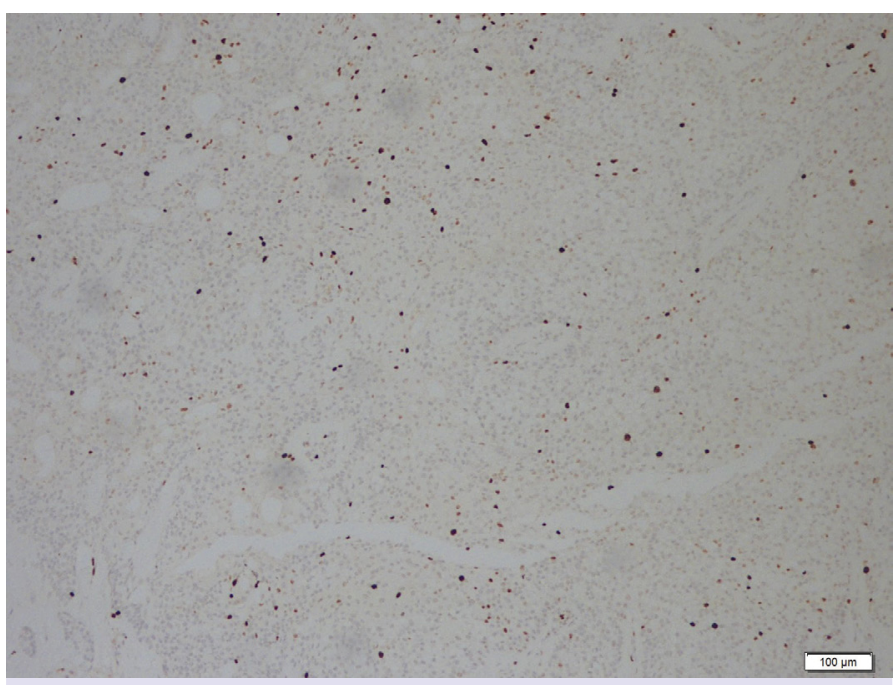

FIGURE 6 . Ki-67 index is $5 \%$ in the most intense area.

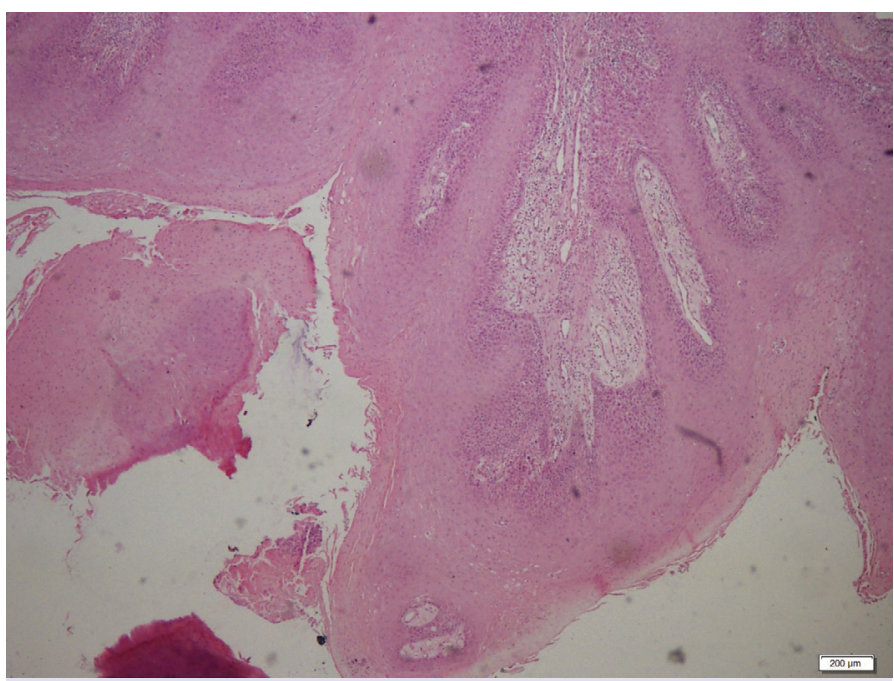

FIGURE 7. Verrucous carcinoma. Parakeratosis, acanthosis, verrucous growth pattern, mitosis on the basal and middle layer and minimal loss of polarity are seen. There is no invasion here.

salivary glands is $5.1 \%$; only one case involved the buccal mucosa [7].

Histopathologically, EMC is characterized by a glandular structure consisting of inner epithelial cells and outer myoepithelial cells. The inner layer is composed of cuboid or low columnar ductal epithelial cells with eosinophilic cytoplasm and round central nuclei. The outer layer consists of polygonal large myoepithelial cells with eccentric nuclei and the cytoplasm is pale or clear [3]. The external basement membrane underlies the myoepithelial cells. The stroma consists of almost acellular collagen. Rarely, tumors may invade the blood vessels or 


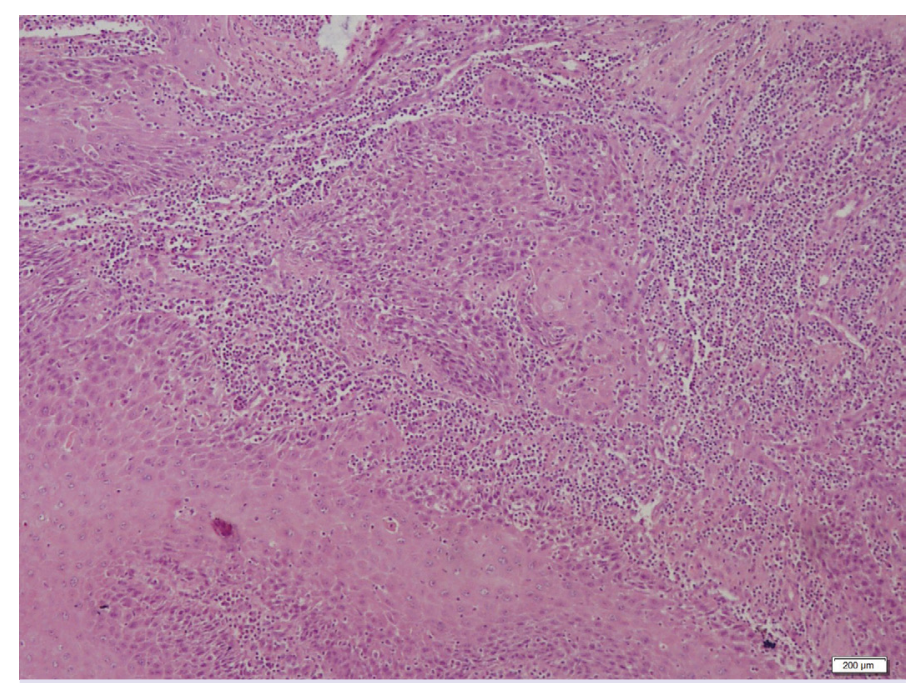

FIGURE 8. Microinvasion of verrucous carcinoma in the left vocal cord.

perineurium. Mitotic figures and nuclear pleomorphism are rarely present [1]. Immunohistochemical staining is essential to identify the double layer cell morphology in this tumor. The inner-layer cells are positive for $c y-$ tokeratin, EMA, and carcinoembryonic antigen, and the outer-layer cells are positive for SMA, p-63, S-100, and vimentin $[1,4]$. In the present case, the double structure was recognized by CK7, EMA, p40 positivity.

Myoepitheliomas, myoepithelial carcinomas, clear cell oncocytomas, clear cell carcinomas, acinic cell carcinomas, mucoepidermoid carcinomas, and metastatic clear cell tumors are the clear cell dominated tumors which are in the differential diagnosis of EMC [1].

Epithelial-myoepithelial carcinoma has the double layer of inner cuboidal epithelial cells and outer clear myoepithelial cells. Myoepithelioma and myoepithelial carcinoma are composed of the only myoepithelial cell layer. Immunohistochemistry can help to separate the two layers when they are histopathologically indistinct [8]. Oncocytoma may sometimes be dominated by clear cells, but mostly typical oncocytes are present. The clear cells often have pale granular cytoplasm with PAS-positive granules in oncocytoma [9]. Clear-cell carcinoma is seen in minor salivary glands and the tumor cells do not express S-100 for myoepithelial differentiation [10]. The clear cells in acinic cell carcinoma are not generally true clear cells. They represent a fixation artefact. The characteristic secretory granules of normal acinic cell carcinoma can be seen with a careful search [11]. The clear cells of mucoepidermoid carcinoma contain PAS- positive neutral mucin and squamous differentiation. Clear cells in a salivary gland tumor can originate from metastatic carcinoma. The immunohistochemical profile of renal carcinoma is different from salivary gland and has not the biphasic pattern of epithelial-myoepithelial carcinoma [12].

Local recurrence of EMC found $23 \%$ to $50 \%$ of cases, lymph node metastases found $17 \%$ to $23 \%$, and distant metastases to lung, kidney and brain found $8-10 \%$ of the cases $[13,14]$. EMC is characterized by a relatively good prognosis. If tumor size is $4 \mathrm{~cm}$ or more, solid tumors predominantly clear cells, forming nests and sheaths, the prognosis is worse [15].

Our case is located in minor salivary gland in oral, buccal area and macroscopically caused ulceration on the lower lip cutaneous side. Verrucous carcinoma on the vocal cord is detected synchronously in this patient. Morphologically, there were two separate lesions and no similarity between EMC and microinvasive verrucous carcinoma.

In conclusion, the EMC of minor salivary glands is very rare. To our knowledge, its ulceration effect on the skin has not been reported in any study. EMC can be found with other salivary gland tumors [16]. To our knowledge, there are no data about the coexistence of EMC and the tumor of the different anatomic site in the literature. The present case is unique for its location, clinical presentation, coexistence with microinvasive verrucous carcinoma of the vocal cord. EMC in minor salivary glands and its involvement of other sites deserve wider recognition.

Informed Consent: Written informed consent was obtained from the patient for the publication of the case report and the accompanying images.

Conflict of Interest: No conflict of interest was declared by the authors.

Financial Disclosure: The authors declared that this study has received no financial support.

Authorship Contributions: Concept - BCG, IEZ; Design - BCG, IEZ; Supervision - IEZ; Materials - BCG, MHK, BK; Data collection and/or processing - BCG, BK, MHK; Analysis and/or interpretation BCG, IEZ, MA, HNI; Literature review - BCG, IEZ, MA, HNI; Writing - BCG, IEZ, MA, HNI, MHK, BK; Critical review - BCG, IEZ.

\section{REFERENCES}

1. Giriyan SS, Agrawal A, Reddy P, Chandan RH. Epthelial Myoepithelial Carcinoma: A Rare Salivary Gland Neoplasm. International Journal of Science and Research (IJSR) 2016;5:896-9.

2. Donath K, Seifert G, Schmitz R. Diagnosis and ultrastructure of the 
tubular carcinoma of salivary gland ducts. Epithelial-myoepithelial carcinoma of the intercalated ducts. [Article in German]. Virchows Arch A Pathol Pathol Anat 1972;356:16-31. [CrossRef]

3. Seifert G, Sobin LH. Epithelial-Myoepithelial Carcinoma. In: World Health Organization International Histo-logical Classification of Tumours. Histological Typing of Salivary Gland Tumours. 2nd ed. Berlin: Springer-Veflag; 1991.p. 23-4. [CrossRef]

4. Angiero F, Sozzi D, Seramondi R, Valente MG. Epithelial-myoepithelial carcinoma of the minor salivary glands: immunohistochemical and morphological features. Anticancer Res 2009;29:4703-9.

5. Politi M, Robiony M, Avellini C, Orsaria M. Epithelial-myoepithelial carcinoma of the parotid gland: Clinicopathological aspect, diagnosis and surgical consideration. Ann Maxillofac Surg 2014;4:99-102. [CrossRef]

6. Guan M, Cao X, Wang W, Li Y. Epithelial-myoepithelial carcinoma of the hypopharynx: A rare case. Oncol Lett 2014;7:1978-80. [CrossRef]

7. Tsuji T, Kitada H, Abe S, Ikeda H, Nakayama E. Epithelial-myoepithelial carcinoma of a minor salivary gland in the buccal mucosa. Oral Radiol 2015;32. [CrossRef]

8. Simpson RH, Clarke TJ, Sarsfield PT, Gluckman PG. Epithelial-myoepithelial carcinoma of salivary glands. J Clin Pathol 1991;44:419-23.
9. Ellis GL. "Clear cell" oncocytoma of salivary gland. Hum Pathol 1988;19:862-7. [CrossRef]

10. Simpson RH, Sarsfield PT, Clarke T, Babajews AV. Clear cell carcinoma of minor salivary glands. Histopathology 1990;17:433-8. [CrossRef]

11. Batsakis JG. Clear cell tumors of salivary glands. Ann Otol Rhinol Laryngol 1980;89:196-7. [CrossRef]

12. Melnick SJ, Amazon K, Dembrow V. Metastatic renal cell carcinoma presenting as a parotid tumor: a case report with immunohistochemical findings and a review of the literature. Hum Pathol 1989;20:195-7.

13. Ordonez BP. Selected topics in salivary gland tumour pathology. Current Diagnostic Pathology 2003;9:355-65. [CrossRef]

14. Friedrich RE, Donath K. Epithelial-myoepithelial carcinoma of the parotid gland with multiple distant metastases: a case report. J Oral Maxillofac Surg 2000;58:690-4. [CrossRef]

15. Shruthi H, Sumona P. Epithelial Myoepithelial Carcinoma- A Rare Case Report. Bangladesh Journal of Medical Science 2012;11:129-33.

16. Kusafuka K, Takizawa Y, Ueno T, Ishiki H, Asano R, Kamijo T, et al. Dedifferentiated epithelial-myoepithelial carcinoma of the parotid gland: a rare case report of immunohistochemical analysis and review of the literature. Current Diagnostic Pathology 2002;8:328-37. 